\title{
Development of an autonomous sea ice tethered buoy for the study of ocean-atmosphere-sea ice-snow pack interactions: the O-buoy
}

\author{
T. N. Knepp ${ }^{1}$, J. Bottenheim ${ }^{2}$, M. Carlsen ${ }^{3}$, D. Carlson ${ }^{4}$, D. Donohoue ${ }^{4}$, G. Friederich ${ }^{5}$, P. A. Matrai ${ }^{6}$, S. Netcheva ${ }^{2}$,

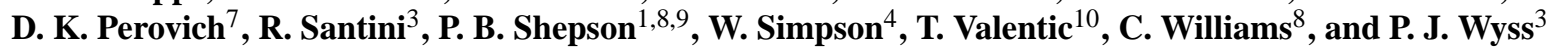 \\ ${ }^{1}$ Purdue University, Department of Chemistry, 560 Oval Dr., West Lafayette, IN 47907, USA \\ ${ }^{2}$ Environment Canada, Toronto, Canada, 4905 Dufferin Street, Toronto, Ontario M3H 5T4, Canada \\ ${ }^{3}$ Jonathan Amy Facility for Chemical Instrumentation, Purdue University, 560 Oval Dr., West Lafayette, IN 47907, USA \\ ${ }^{4}$ University of Alaska Fairbanks, Department of Chemistry \& Biochemistry, University of Alaska Fairbanks, AK 99775-6160, \\ USA \\ ${ }^{5}$ Monterey Bay Aquarium Research Institute, 7700 Sandholdt Rd., Moss Landing, CA 95039, USA \\ ${ }^{6}$ Bigelow Laboratory for Ocean Sciences, 180 McKown Pt., West Boothbay Harbor, ME 04575, USA \\ ${ }^{7}$ US Army Corps of Engineers Cold Regions Research and Engineering Laboratory, 72 Lyme Rd., Hanover, NH 03755, USA \\ ${ }^{8}$ Purdue University, Department of Earth and Atmospheric Sciences, West Lafayette, IN 47907, USA \\ ${ }^{9}$ Purdue Climate Change Research Center, Purdue University, West Lafayette, IN 47909, USA \\ ${ }^{10}$ SRI International, 333 Ravenswood Ave., Menlo Park, CA 94025, USA
}

Received: 31 July 2009 - Published in Atmos. Meas. Tech. Discuss.: 2 September 2009

Revised: 5 February 2010 - Accepted: 5 February 2010 - Published: 17 February 2010

\begin{abstract}
A buoy based instrument platform (the "O-buoy") was designed, constructed, and field tested for year-round measurement of ozone, bromine monoxide, carbon dioxide, and meteorological variables over Arctic sea ice. The O-buoy operated in an autonomous manner with daily, bi-directional data transmissions using Iridium satellite communication. The O-buoy was equipped with three power sources: primary lithium-ion battery packs, rechargeable lead acid packs, and solar panels that recharge the lead acid packs, and can fully power the O-buoy during summer operation. This system was designed to operate under the harsh conditions present in the Arctic, with minimal direct human interaction, to aid in our understanding of the atmospheric chemistry that occurs in this remote region of the world. The current design requires approximately yearly maintenance limited by the lifetime of the primary power supply. The O-buoy system was field tested in Elson Lagoon, Barrow, Alaska from February to May 2009, and deployed in the Beaufort Sea in October 2009. Here, we describe the design and present preliminary data.
\end{abstract}

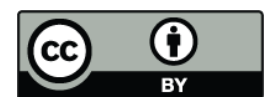

Correspondence to: P. A. Matrai ( pmatrai@bigelow.org)

\section{Introduction}

The Arctic has been a source of fascination and study since the time of Aristotle (Strabo, 1966), with significant scientific interest and discovery beginning in the early twentieth century (Whitfield, 1900; Warren, 1911). Polar regions are unique in that atmosphere/surface interactions, which determine the composition of the troposphere, are significantly impacted by air-ice (e.g. aerosol, gas, snow) heterogeneous physical and chemical processes.

During polar spring, air masses that are in contact with sea ice undergo significant ozone depletion events (ODEs) in which the mole fraction of tropospheric ozone decreases to nearly zero in a relatively short period of time (e.g. one day). These ODEs were first observed in the mid-1980s (Bottenheim et al., 1986; Oltmans and Komhyr, 1986; Barrie et al., 1988), and have continued to be a source of intense study. Such ODEs are believed to result from bromine chemistry that catalytically destroys ozone (Barrie et al., 1988), with inter-halogen reactions (especially those with chlorine) possible. Satellite (Richter et al., 1998; Wagner and Platt, 1998; Kaleschke et al., 2004) and other observations (Simpson et al., 2007a) indicate that air masses that have been in contact with sea ice, particularly the saline first-year sea ice,

Published by Copernicus Publications on behalf of the European Geosciences Union. 
exhibit halogen chemistry and ozone depletion, leading to the conclusion that sea salt is the primary halogen source (Fan and Jacob, 1992; Tang and McConnell, 1996; Simpson et al., 2007b). However, the mechanism by which sea salts are converted to reactive halogen gases is unclear, and a number of theories exist. Frost flower surfaces have been proposed to be involved (Rankin et al., 2000), and a number of studies have investigated this hypothesis (Kaleschke et al., 2004; Dominé et al., 2005; Kalnajs and Avallone, 2006). Snow contaminated with sea salts may also hold a key role (Impey et al., 1997; Dominé and Shepson, 2002; Simpson et al., 2005, 2007a). Direct production of halogen gases from a salt-contaminated snowpack has been observed (Foster et al., 2001), as well as indirect observations of halogen losses from snowpack (Simpson et al., 2007b; AlvarezAviles et al., 2008). Aerosol surfaces, possibly from the dispersal of frost flowers, are also a candidate (Fan and Jacob, 1992; Kaleschke et al., 2004). Modeling studies have also attempted to simulate halogen activation and ozone depletion.

Global atmospheric $\mathrm{CO}_{2}$ mole fractions are at the highest levels of the past 25 million years. Current levels of $\mathrm{CO}_{2}$ have increased by $35 \%$ from 280 parts per million (ppm) in pre-industrial times to $\sim 387 \mathrm{ppm}$ today, and they continue to rise. For the decade of the 1990s, an average of about $6.3 \mathrm{PgC}$ per year as $\mathrm{CO}_{2}$ was released to the atmosphere from the burning of fossil fuels (Ding et al., 2001). Only half, on average, of the $\mathrm{CO}_{2}$ from anthropogenic emissions has remained until now in the atmosphere (Ciais et al., 1995; Keeling et al., 1996; Battle et al., 2000). Analyses of the decreasing ${ }^{13} \mathrm{C} /{ }^{12} \mathrm{C}$ and $\mathrm{O}_{2} / \mathrm{N}_{2}$ ratios in the atmosphere have shown that land and oceans have sequestered the other half, in approximately equal proportions but with temporal and spatial variations. The Arctic Ocean is usually not included in these calculations as models presume a sea-ice capped region without much ocean/sea ice/atmosphere exchange. Because global climate models show large deviations in their simulations of current conditions in the Arctic region (Proshutinsky et al., 2005), the effect of changing ice cover (at $~ 7 \%$ decrease/decade; Comiso, 2002) and thickness on $p \mathrm{CO}_{2}$ fluxes in the Arctic Ocean is not clear. Furthermore, the role of sea ice as a barrier to, or an integral player of, $\mathrm{CO}_{2}$ air/sea and/or air/ice fluxes (Papakyriakou et al., 2004; Semiletov et al., 2004) is least understood, with both the direction and amount of $\mathrm{CO}_{2}$ transfer between air and sea/ice varying in the thaw/freeze and open water seasons due to sea-ice melt ponds, open brine channels, leads and photosynthesis.

It is important to note that the Arctic has changed rapidly over the past fifty years (Holland et al., 2006; Lindsay and Zhang, 2006), with large increases in first year sea-ice. This will likely induce significant changes in the surface interactions with respect to ODEs, and the extent to which the Arctic Ocean will become a more important sink for $\mathrm{CO}_{2}$. Climate models predict a predominantly ice-free Arctic Ocean in summer by the end of the century (Johannessen et al., 2004; Holland et al., 2006; Stroeve et al., 2007), implying a change in the sea-air fluxes of $\mathrm{CO}_{2}$. Validation of such models will require independent information on spatial and temporal patterns of $\mathrm{CO}_{2}$ sources and sinks in the Arctic Ocean in order to improve our ability to predict future regional and global $\mathrm{CO}_{2}$ fluxes.

Though there have been many land-based measurements throughout the Arctic, these measurements have been spatially limited (e.g. no measurements from the Siberian side of the Arctic Ocean), with the majority of campaigns taking place in the spring. Additionally, there have been several late-spring and summer ice breaker cruises (Weller and Schrems, 1996; Jacobi et al., 2006) to study a variety of atmospheric and oceanic phenomena over the sea ice; however, such cruises are relatively short, often spatially limited, and expensive due to the cost of ice breaker operation. Such limited efforts, though extremely useful, fail to provide a full picture of atmospheric chemical processes over the Arctic Ocean as a function of time and space, especially in the more remote northern latitudes and during the dark winter/early spring months. Acquisition of year-round measurements of atmospherically relevant chemical species and meteorological parameters will be highly elucidative for the purpose of understanding chemical mechanisms, transport pathways/processes, and understanding the necessary conditions for Arctic unique chemistry.

Acquisition of such data has proven to be difficult and potentially dangerous to researchers and instrumentation due to the extremely harsh environment in the Arctic: e.g. extreme low winter temperatures, variable sea-ice conditions, seaspray, and wildlife. To date, there have been very few surface $\mathrm{CO}_{2}, \mathrm{BrO}$, or $\mathrm{O}_{3}$ measurements over the Arctic Ocean, although there are land-based year-round monitoring stations at Barrow, Alert, and Zeppelin Station. The only long term record of $\mathrm{O}_{3}$ observations over the Arctic Ocean has recently been obtained during the 16 month drift of the schooner TARA (Bottenheim et al., 2009). For several years, the International Arctic Buoy Program (IABP) has successfully monitored sea-ice and ocean temperatures/salinity (Rigor et al., 2000; Haas et al., 2008). However, the IABP has, to date, not studied the chemistry occurring in this region. Clearly, there is a significant gap in our understanding of this region as compared to other, more accessible regions of the world, and more work must be done. To this end, an autonomous sea-ice tethered, buoy-based instrument platform, capable of operating under Arctic Ocean conditions for a time period on the order of a year to record gas-phase $\mathrm{O}_{3}, \mathrm{CO}_{2}$, and $\mathrm{BrO}$ data, with daily transmission of data via satellite, was developed. We discuss the details of this O-buoy and its performance during a test phase deployment at Barrow, AK herein. 


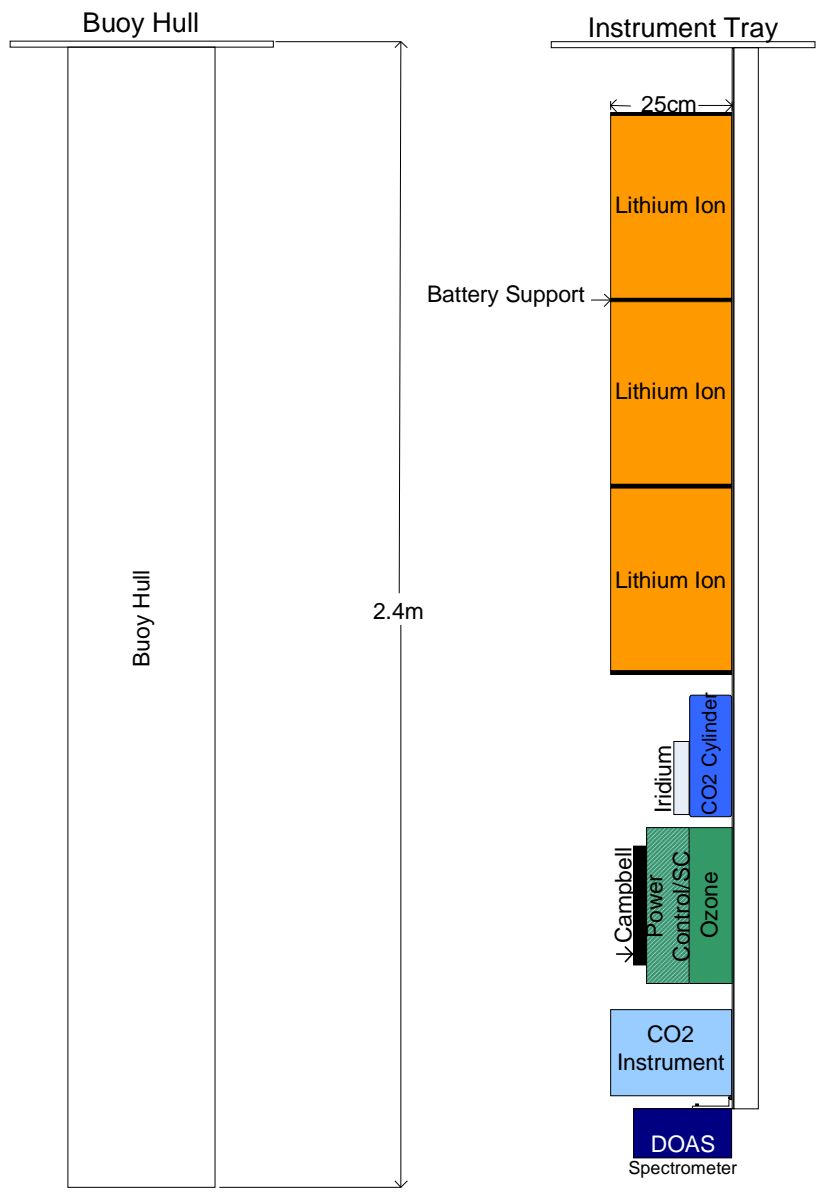

Fig. 1. Schematic drawing of the O-buoy hull and instrumentation placement on the instrument panel.

\section{Instrumentation}

\subsection{O-buoy hull and mast}

An autonomous O-buoy system capable of year-round measurement of $\mathrm{O}_{3}, \mathrm{CO}_{2}$, and $\mathrm{BrO}$, while deployed in sea-ice, was designed and constructed. A critical design objective for the O-buoy was to operate the instruments with (necessary) temperature control, but at minimal power cost, since winter operation is powered via on-board batteries. Thus, the design put the three main instruments at the bottom of the O-buoy, which was immersed in the sea-water below the ice, to maintain near constant temperature (i.e. $-1.5^{\circ} \mathrm{C}$ ).

The O-buoy hull was constructed from quarter-inch $(6 \mathrm{~mm})$ aluminum at the US Army Corps of Engineers Cold Regions Research and Engineering Laboratory (CRREL) in New Hampshire, and is represented schematically in Figs. 1-2. The main O-buoy housing was an aluminum cylinder $2.4 \mathrm{~m}$ long and $0.3 \mathrm{~m}$ in diameter. Three primary lithium battery packs, two cylinders containing $\mathrm{CO}_{2}$ calibration gases (at $368.6 \mathrm{ppm}$ and $396.6 \mathrm{ppm}$ ), Iridium communication equipment, the $\mathrm{O}_{3}$ instrument, power control

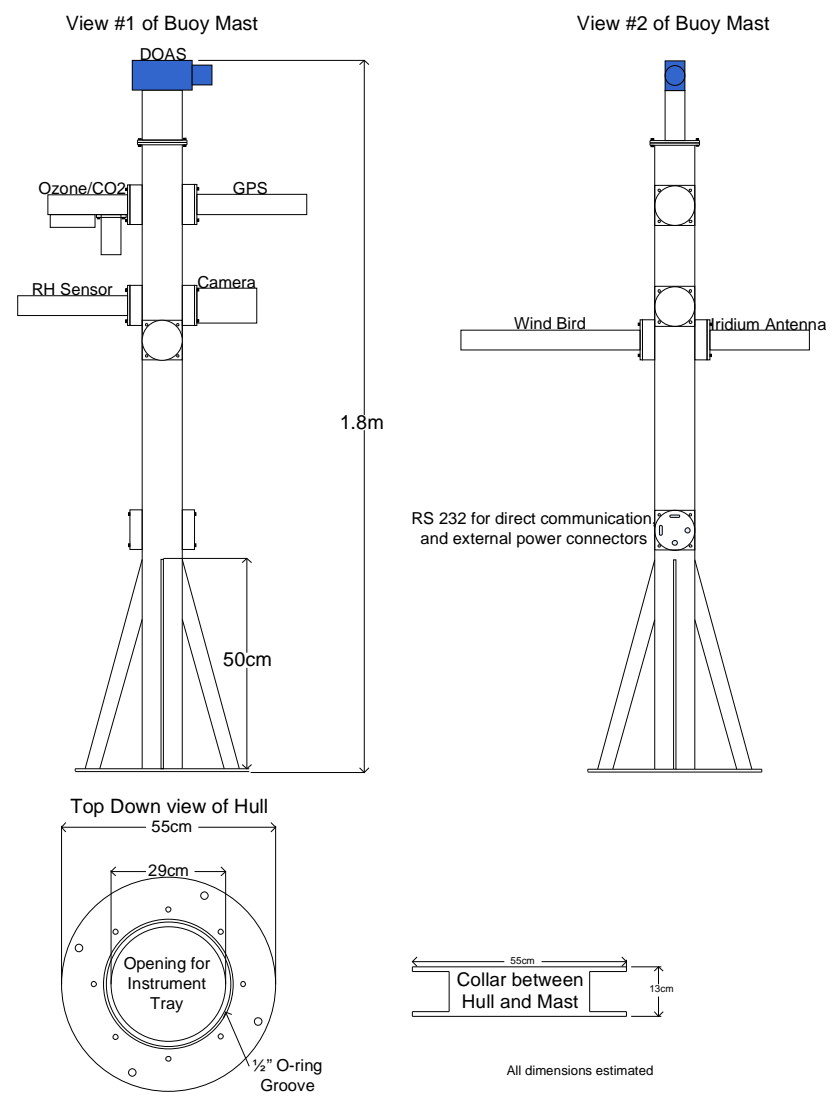

Fig. 2. A schematic representation of the O-buoy's mast and hullto-mast connecting collar. View 2 is a rotation of view 1 about the $\mathrm{y}$-axis by $90^{\circ}$ to allow visualization of all instrument/inlet mounts on the mast.

and supervisory computer, data logger (CR1000 Campbell Scientific Instruments), Iridium modem, $\mathrm{CO}_{2}$, and MultiAXis Differential Optical Absorption Spectroscopy (MAXDOAS) instrument were placed inside the main housing. A $2 \mathrm{~m}$ high tower was placed on top of the hull, from which meteorological sensors, camera, global positioning system (GPS), and the MAX-DOAS's scan head were mounted (Fig. 2). Connections were made between the tower and the main housing using Amphenol Class E Environmental connectors. A flotation collar (Gilman Corporation Type 1000) provided buoyancy in case the O-buoy melted free of the ice. The collar was $1.1 \mathrm{~m} \mathrm{OD} \times 0.64 \mathrm{~m} \mathrm{H}$ and provided $482 \mathrm{~kg}$ of buoyancy. The instruments, computer, and lithium-ion batteries were secured to an aluminum tray (Fig. 1) that could be slid into, and out of, the hull. The tray was constructed of eighth-inch $(3 \mathrm{~mm})$ aluminum with aluminum supports. The overall dimensions of the O-buoy were $4.2 \mathrm{~m}$ tall, $1.1 \mathrm{~m}$ wide, and $280 \mathrm{~kg}$.

Previous buoys deployed by CRREL have had multi-year lifetimes. This buoy underwent a two month test phase in a cold room (temperature $-20^{\circ} \mathrm{C}$ ) at CRREL and was then tested in Barrow from December 2008 - May 2009. From the successful operation of the O-buoy's instrumentation during 


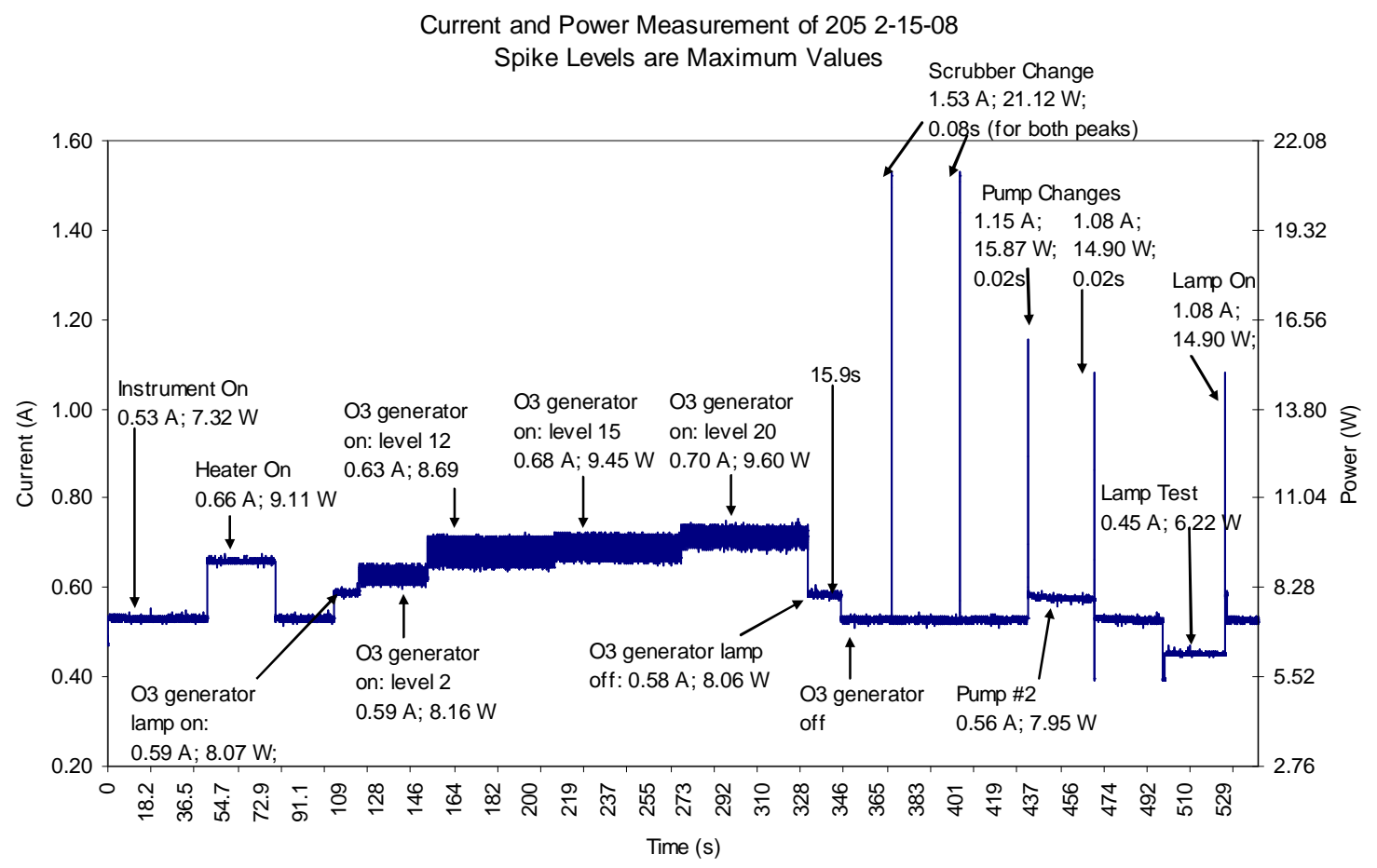

Fig. 3. Power plot of the ozone instrument in its various states of operation. In its baseline operation state the instrument draws approximately $7.3 \mathrm{~W}$. Such a power measurement was done for all instruments on the O-buoy.

this time, and the subsequent deployment in the Beaufort Sea, we believe the system to be capable of surviving a full annual cycle.

\subsection{Ozone instrument}

Ozone was measured with a 2B Technologies model 205 dual-beam UV-absorption sensor that was specially constructed for this endeavor. The ozone instrument provides a limit of detection of approximately 1 parts per million (ppb) (i.e. better than that necessary to observe depletion events, from background levels of $\sim 35 \mathrm{ppb}$ ). It functions by UV-absorption at $254 \mathrm{~nm}$, with one flow path scrubbed of $\mathrm{O}_{3}$ for the $\mathrm{I}_{0}$ measurement of a Beer-Lambert calculation. The ozone instrument's modifications involved addition of a lamp heater, a back-up pump, back-up ozone scrubber, an ozone generator, and the ability to remotely control the instrument's state, the ozone generator's output, the state of the lamp heater, and the ability to switch the pump and scrubber. The ozone instrument was housed in an aluminum case (positioned approximately $0.5 \mathrm{~m}$ from the bottom of the O-buoy, Fig. 1), with the lid acting as the bottom of the power control board and supervisory computer case. The electrical connectors between the inside and outside of the ozone instrument's case were Amphenol connectors, and the plumbing connections were PTFE Teflon Swagelok. The sample inlet line was $4 \mathrm{~mm}$ PTFE Teflon (4 m long), and the exhaust line was $8 \mathrm{~mm}$ PTFE Teflon ( $4 \mathrm{~m}$ long). The inlet line was inserted into the exhaust line to make a coaxial configuration, which allowed the outlet gas to warm the inlet gas, thus reducing the chance of condensation on the lines. The sample lines were connected between the mast and hull using a custom built bulkhead which maintained the coaxial configuration. The lines were configured in such a way that the exhaust exited the mast at a distance of approximately one meter from the inlet. The ozone instrument's inlet was approximately $1.5 \mathrm{~m}$ up on the mast, and had a $90 \mathrm{~mm}$ quartz fiber filter (Pall Life Sciences Membrane Filter) held in place by a machined stainless steel filter holder.

Due to the limited power supply, power minimization for each instrument was extremely important. As compared to other UV absorption ozone sensors, the 2B 205 is a relatively low power instrument. The power consumed in a variety of operation states was recorded and plotted (Fig. 3; average $7.3 \mathrm{~W}$ ). Figure 3 is representative of the type of power measurements done for each instrument on the O-buoy. Such information was useful not only for budgeting power, but also for minimizing the risk of system failure due to transient draws from multiple components. The ozone instrument was operated for three hours per-day (centered around solar noon) from 11 February to 2 March. For the purpose of testing the instrument's ability to continuously operate under Arctic conditions, and for obtaining higher resolution data, the ozone instrument collected data all day (10 s averages; except during data transmission) from 2 March to the time the O-buoy was recovered on 19 May. However, during future, non-test phase deployments, all instruments will have the predefined duty cycles as outlined in Table 1. 
Table 1. Monthly energy consumption (Wh) for each instrument/component of the O-buoy. Each monthly value accounts for each instrument's power draw and duty cycle in normal deployment mode.

\begin{tabular}{lrrrrrrrrrrrrrr}
\hline Component & Jan & Feb & Mar & Apr & May & Jun & Jul & Aug & Sep & Oct & Nov & $\begin{array}{r}\text { Dec } \\
\begin{array}{r}\text { Annual } \\
\text { Wh }\end{array}\end{array}$ & $\begin{array}{r}\text { Percent } \\
\text { Power }\end{array}$ \\
\hline DOAS & 0 & 373 & 535 & 674 & 535 & 546 & 546 & 482 & 578 & 450 & 0 & 0 & 4720 & $14 \%$ \\
Ozone & 75 & 686 & 1082 & 1082 & 1345 & 247 & 247 & 247 & 445 & 247 & 75 & 75 & 5853 & $18 \%$ \\
CO $_{2}$ & 97 & 97 & 97 & 97 & 97 & 97 & 97 & 97 & 97 & 97 & 97 & 97 & 1164 & $3 \%$ \\
Supervisory & 1684 & 1684 & 1684 & 1684 & 1684 & 1684 & 1684 & 1684 & 1684 & 1684 & 1684 & 1684 & 20203 & $61 \%$ \\
Computer & & & & & & & & & & & & & & \\
GPS & 33 & 33 & 33 & 33 & 33 & 33 & 33 & 33 & 33 & 33 & 33 & 33 & 395 & $1 \%$ \\
Iridium & 39 & 74 & 100 & 127 & 100 & 102 & 102 & 89 & 108 & 83 & 39 & 39 & 1001 & $3 \%$ \\
TOTAL & 1928 & 2948 & 3530 & 3696 & 3794 & 2708 & 2708 & 2632 & 2944 & 2593 & 1927 & 1927 & 33336 & $100 \%$ \\
\hline
\end{tabular}

Calibration: Though the ozone instrument's internal processor accounts for cell temperature and pressure fluctuations in the calculation of ozone mole fraction, verification of the accuracy/precision of this calculation was performed. The ozone instrument was calibrated as a function of environment/cell temperature by placing it in a temperature controlled freezer (Fig. 4) at Purdue University before deployment. The ozone instrument was controlled through a serial connection to a Linux box, and supplied with ozone from a TECO-49 ozone generator. The TECO's ozone generation was self-monitored to allow subtraction of any fluctuations in its production from the 205's signal. The slopes and intercepts for the different temperatures were not statistically significantly different $(<2 \sigma$; i.e. there was no temperature dependence of instrument sensitivity over the range of possible operating temperatures during deployment). Additionally, changing the pump or scrubber had no affect on the reported $\mathrm{O}_{3}$ mole fraction.

The ozone instrument underwent a one-time field calibration at the time of deployment using a $2 \mathrm{~B}$ Technologies model 306 ozone generator (output flow rate $2.5 \mathrm{~L} \mathrm{~min}^{-1}$ ). The ozone generator required an internal temperature of $40^{\circ} \mathrm{C}\left( \pm 1^{\circ} \mathrm{C}\right)$ to produce consistent mole fractions of ozone. Since the ambient temperature was $-30^{\circ} \mathrm{C}$ the ozone generator was operated in a heated tent next to the O-buoy with additional heating from heat tape that was wrapped around the instrument with the applied voltage controlled by a variac, with power supplied by a generator. The ozone generator was programmed to produce $0 \mathrm{ppb}, 5 \mathrm{ppb}, 15 \mathrm{ppb}, 30 \mathrm{ppb}, 55 \mathrm{ppb}$, and $95 \mathrm{ppb}$ ozone for five minutes for each standard sample. The ozone generator's outlet (1/4" PTFE Teflon tube; $7 \mathrm{~m}$ long) was connected to the ozone filter inlet on the O-buoy. The filter inlet was covered tightly with aluminum foil, and this volume was swept (at $2.5 \mathrm{~L} \mathrm{~min}^{-1}$ ), with the ozone generator standard gas flow, via a hole in the foil, allowing all air in this volume to be purged with the standard gas. We are confident that there was no mixing of outside air that would alter the calibration gas for the O-buoy's ozone instrument as that instrument sampled at a rate of $750 \mathrm{~mL} \mathrm{~min}^{-1}$ as compared to the generator's flow rate of $2.5 \mathrm{~L} \mathrm{~min}^{-1}$.

The lab-based cold chamber calibrations and the field calibration immediately prior to deployment had statistically indifferent slopes and intercepts at the 95\% confidence level. These calibrations were separated by more than a year, indicating both the sensitivity and accuracy to be invariant over that time period. During deployment the ozone monitor can perform zero and span measurements to test the instrument's functionality. Further, during the test phase deployment, the ozone data were compared to data collected at NOAA's Barrow site. The agreement of these data was within $1.6 \mathrm{ppb}$ over the entire deployment test phase.

\section{$2.3 \quad \mathrm{CO}_{2}$ instrument}

An autonomous $\mathrm{CO}_{2}$ sensor was built around the LI-COR 820 IR instrument, a single path, dual wavelength, nondispersive infrared gas analyzer that allows measurement of absolute concentrations of $\mathrm{CO}_{2}$ in air. This instrument was adapted for buoy deployment as part of the TAO/TOGA buoy array in the equatorial Pacific and for numerous coastal buoys and drifters where the primary focus was the measurement of sea surface $p \mathrm{CO}_{2}$ (Friederich et al., 1995, 2008); see http: //www.pmel.noaa.gov/co2/moorings/. Measurement precision and accuracy were improved by almost an order of magnitude for the O-buoy deployment where the measurement of atmospheric $p \mathrm{CO}_{2}$ was one of the main goals. These improvements were achieved by a combination of careful predeployment calibration, mechanical and electronic filtering, thorough drying of the sample air stream, operation of the measurement cell at the low in-situ temperature and using the deployment calibration data to improve the atmospheric pressure correction algorithm. The precision of the deployed system was about $\pm 0.1 \mathrm{ppm}$ and the accuracy was estimated to be $\pm 0.2 \mathrm{ppm}$ (sufficient to determine any significant change from the seasonal range: $360-400 \mathrm{ppm}$ ) due to uncertainties in the standard gases as well as residual errors in the 
$\mathrm{O}_{3}$ Instrument Temperature Tests

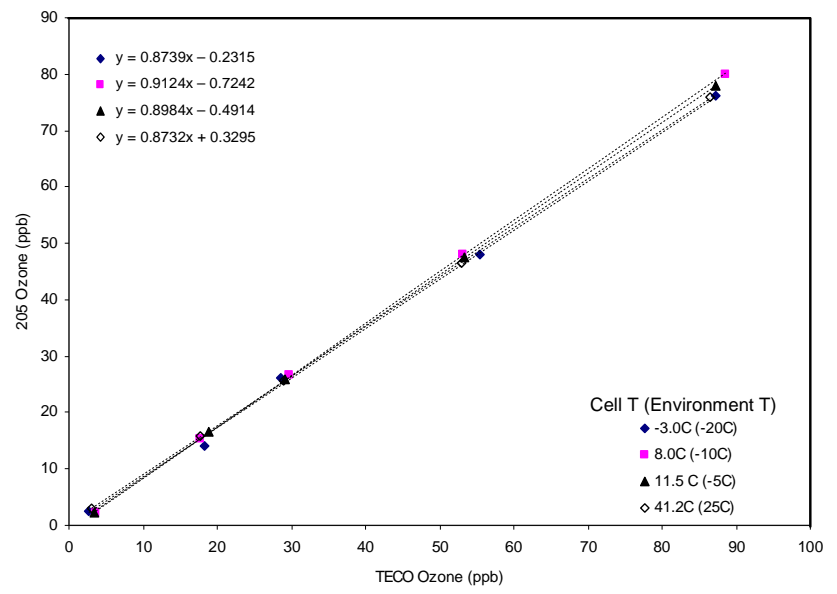

Fig. 4. Temperature dependent calibration of the ozone instrument.

temperature and pressure corrections. Operational details are given below.

The $\mathrm{CO}_{2}$ system was controlled by a low power controller (ONSET TT8v2) equipped with a set of custom made interface boards that scheduled the analyzer, pumps, and valves, collected and formatted the data, and stored all information in flash memory before passing it on to the supervisory computer for transmission. A sampling frequency of 8 measurements per day was selected; this frequency allowed the resolution of significant events while conserving power. A complete sampling cycle took $6 \mathrm{~min}$ and had a mean power consumption of $3.5 \mathrm{~W}$. The standby power consumption was less than $0.04 \mathrm{~W}$. Power requirements were kept low by operating the infrared analyzer at ambient temperature without stabilization. Temperature of the measurement cell was monitored at all phases of the sample cycle and data were corrected to a common temperature using laboratory and field derived calibrations. Another factor that kept power consumption low was the choice of gas switching and distribution valves (ASCO Series AM33) that were magnetically latching and only required a $100 \mathrm{~ms}$ pulse to change position. Gas aspiration and circulation were achieved with a small diaphragm pump (KNF Neuberger UNMP015M) operated at reduced voltage with additional flow restriction to limit gas flows to about $100 \mathrm{~mL} \mathrm{~min}^{-1}$. Prior to entering the infrared analyzer all gases were dried and filtered through $0.22 \mathrm{mi}-$ cron hydrophobic filters. Drying was accomplished in sequential sections of Nafion (Permapure) tubing embedded in molecular sieve 4A. Nafion allows the passage of water vapor but has no effect on $\mathrm{CO}_{2}$ or major components of air and these dryers work especially well at low temperatures (Leckrone and Hayes, 1997). The capacity of these dryers was designed to provide drying of water saturated samples at $0{ }^{\circ} \mathrm{C}$ for several years of sampling. Laboratory tests indicate that the absolute water vapor dilution of the samples was equivalent to less than $0.1 \mathrm{ppm} \mathrm{CO}_{2}$ and that the difference between the water vapor pressure of the standards and the samples was on the order of $0.005 \mathrm{kPa}$, thus generating uncertainties on the order of $0.02 \mathrm{ppm}$ in the final $\mathrm{CO}_{2}$ results. Water vapor changes in the gas stream were estimated with a humidity sensor designed for measurement of low humidity (Humirel HM1520LF) mounted in the outlet of the infrared analyzer.

A complete sampling cycle consisted of several distinct operations that are described below:

Zero (power up): Power is applied to the infrared analyzer which has a "warm up" time of one minute. While waiting for the analyzer to stabilize, the valves in the gas manifold are switched to form a closed loop with the analyzer, pump, a soda lime (mostly $\left.\mathrm{Ca}(\mathrm{OH})_{2}\right)$ cartridge and the Nafion dryers. The pump is started up and the trapped gas is circulated for one minute until all $\mathrm{CO}_{2}$ has reacted with the soda lime and removed from the gas stream. A reading of all parameters $\left(\mathrm{CO}_{2}\right.$, cell temperature, pressure and water vapor) is made immediately before turning the circulation pump off. A second reading is taken $10 \mathrm{~s}$ later; those readings are used in the final calculations of $p \mathrm{CO}_{2}$ since they occur in a more noise-free environment and at a cell pressure that is closer to the ambient atmospheric pressure. Comparison of the two measurements allowed an estimate of pump effectiveness and the condition of the in-line filters. The zero values had a predictable offset of $-1.2 \mathrm{ppm}^{\circ} \mathrm{C}^{-1}$ and had a long-term drift of about $-0.3 \mathrm{ppm}$ per month.

Standards: After determining the instrument response at zero $\mathrm{CO}_{2}$ levels, two gas standards are analyzed sequentially. To conserve standard gases this analysis was performed during alternate sample cycles. The gases were contained in $1 \mathrm{~L}$ aluminum cylinders with stainless steel manifolds at an initial pressure of about $120 \mathrm{~atm}$, thus yielding slightly less than $120 \mathrm{~L}$ of calibration gas at the deployment conditions. Delivery was controlled with a small two stage regulator (Scott Specialty Gases Model 14) coupled to a needle valve. Flow rates were set to $100 \mathrm{~mL} \mathrm{~min}^{-1}$ near the expected internal buoy temperature $\left(-1^{\circ} \mathrm{C}\right)$ and tested over a temperature range of $-40^{\circ} \mathrm{C}$ to $24^{\circ} \mathrm{C}$. Gas delivery increased with decreasing temperature at a rate of about $1 \%$ per degree and good flushing of the analytical system was maintained under all conditions. During a standard cycle the valve manifold opens a path from one of the standard cylinders through the Nafion dryers and into the infrared analyzer. The exhaust is vented to the outside via the outer shell of the atmospheric sampling inlet. Gas flows for one minute after which valves are switched to vent any overpressure to the atmosphere. The procedure is then repeated for the second cylinder. Data were collected when the gas is flowing and when it is stopped and the pressure difference between the two readings is a measure of gas flow. No change in flow rate was detected during the 6 month test phase. The standards indicate that instrument sensitivity at the $400 \mathrm{ppm} \mathrm{CO}_{2}$ level decreased at a rate of about $0.4 \mathrm{ppm}$ per month during the deployment. 
Air Sampling: Following the standard gas analysis, the valve manifold is switched into air sampling mode. In this mode, air is aspirated from the external inlet located on the buoy mast and then passes through the Nafion dryers before entering the infrared analyzer. The exhaust gases exit via the outer shell of the coaxial inlet line. The sample is actively pumped for one minute to flush the analytical manifold. Data were collected before turning the pump off and again after a $10 \mathrm{~s}$ relaxation period. Air enters the inlet system near the top of the buoy mast through a protected hydrophobic 0.45 micron pore size membrane (Pall Supor-450R). The air then enters a length of Nafion tubing in a small chamber which contains the exhaust gas. Since the exhaust gas is always drier than ambient air, the freshly sampled air will have some of its moisture removed and is less likely to form ice in the inlet line while traveling down the mast. The inlet line from the top of the mast to the instrumentation consists of coaxial FEP tubing with the incoming air flowing down in the center and the warmer exhaust gas flowing up in the sheath. This arrangement aids in the temperature equilibration of the incoming air and may decrease the possibility of ice formation in the incoming gas stream; an additional benefit is better organization of tubing inside the mast. Data from the pressure sensor while the system was being pumped indicate that the intake filter and gas path remained unobstructed during the entire deployment.

Zero (power down): Before removing power from the analytical system, a final zero $\mathrm{CO}_{2}$ measurement is obtained in a manner identical to the zero obtained at the start. This procedure put the system in an identical rest state between samples and also provides another temperature calibration point since the final temperature is about one degree higher than the starting temperature.

Calibration: Prior to deployment the instrument was placed in an environmental chamber and subjected to temperatures as low as $-35^{\circ} \mathrm{C}$ to examine the limits of operation. At temperatures below $-25^{\circ} \mathrm{C}$ the gas switching valves became unreliable and power consumption of the gas circulation pump increased; the infrared analyzer continued to operate reliably at all temperatures. Since it was expected that the internal buoy temperature would remain near the freezing point of seawater $\left(\sim-1.9^{\circ} \mathrm{C}\right)$, we limited the testing and calibration to temperatures between $-20^{\circ} \mathrm{C}$ and $5^{\circ} \mathrm{C}$. During the Barrow deployment the temperature of the $\mathrm{CO}_{2}$ instrument ranged from $-0.5^{\circ} \mathrm{C}$ to $-2.8^{\circ} \mathrm{C}$. Laboratory calibration consisted of operating the instrument at a variety of temperatures $\left(-20^{\circ} \mathrm{C}\right.$ to $\left.5^{\circ} \mathrm{C}\right)$ and supplying it with up to six standard gases ranging from $200 \mathrm{ppm}$ to $600 \mathrm{ppm} \mathrm{CO}_{2}$ in air. The gases were obtained from the National Oceanic and Atmospheric Administration's (NOAA) Earth Systems Research Laboratory (ESRL). The calibration obtained in the laboratory was augmented in the field with a 3-point calibration done via a soda lime chamber to generate a zero standard and two small, high pressure $\mathrm{CO}_{2}$ gas standards contained in the buoy housing. The two gas standards (368.6 and $396.6 \mathrm{ppm}$ supplied by ESRL) spanned the annual range of $p \mathrm{CO}_{2}$ that has been observed at the NOAA Barrow Observatory in recent years. Standard gas calibrations were performed 4 times per day throughout the campaign and a $24 \mathrm{~h}$ running mean was utilized to make final adjustments to the data stream. Deployment data also indicated that there was a small residual pressure correction that was not implemented in the original infrared analyzer firmware. The pressure correction adjustment was derived empirically from the analysis of the standards during the deployment and then applied to the entire record. These data were compared to $\mathrm{CO}_{2}$ data collected at NOAA's Barrow observatory. The agreement between the two data sets was consistently within $2 \mathrm{ppm}$.

\subsection{MAX-DOAS (BrO instrument)}

The MAX-DOAS instrument used in this study is described in detail in Carlson et al. (2009), and was tested extensively in Barrow, AK; we provide a brief description here. The MAX-DOAS instrument observes scattered light spectra and derives the slant column abundance of UV-absorbing gases in the observation path (e.g. $\mathrm{BrO}, \mathrm{IO}, \mathrm{O}_{3}, \mathrm{NO}_{2}, \mathrm{HONO}$, etc.) as a function of view elevation angle in the atmosphere (Hönninger et al., 2004). These "elevation scans" can be inverted to give vertical profiles of the absorbers. The technique is analogous to satellite remote-sensing techniques, but with enhanced sensitivity to boundary-layer gases and vertical profiling capabilities; therefore, the system may provide insight into satellite measurements of BrO. Similar MAX-DOAS instruments have been used at fixed groundbased locations in the Arctic to observe halogen chemistry (Hönninger and Platt, 2002; Hönninger et al., 2004; Simpson et al., 2007b).

The instrument consisted of two portions, the scan head, which resided above the sea ice to receive skylight, and the computer/spectrometer, which resided below the ice for better temperature stability, with the two being connected by a fiber optic cable. The scan head oriented a narrowfield telescope to scan the sky for scattered radiation and then this skylight was coupled into the fiber optic connected to the spectrometer for spectral analysis. The computer/spectrometer module consisted of a low-power singleboard computer (Technologic Systems TS-7260), a stepper motor driver (Stepperboard BC2D15), interface electronics, and a miniature charge-coupled device based spectrometer (Ocean Optics HR2000, 318-455 nm).

The scan head had two important features for long-term autonomous operations: defrost and tilt sensing. The defrost system used a near-ultraviolet $(395 \mathrm{~nm})$ light emitting diode (LED) to illuminate the optical input window at an oblique angle. If the window was clear, little of the LED light was scattered into the optical axis of the spectrometer, while when snow or frost was present, LED light was scattered into the spectrometer's field of view. Based upon the 
difference of light detected by the spectrometer at the LED wavelength with the LED on minus LED off, we quantified the degree of frost coverage and turned on a heater if the frost signal exceeded a user-defined threshold. The tilt sensing system used a digital inclinometer (Smart Tool Technologies ISU-S) to measure the tilt of the scan head housing. We used this housing tilt to correct the horizon setting of the stepper motor to maintain accurate alignment of the view directions with respect to the true horizon. If the O-buoy's tilt were to have changed due to ice deformation or a curious polar bear, the instrument was capable of adjusting up to 20 degrees of tilt. Further, the MAX-DOAS was constructed with no external moving parts that could freeze, and the sealed scan head was packed with desiccant to keep it dry and prevent internal freezing. The stepper motor has 36:1 reduction gearing and can be run at higher current to increase torque if there was a problem with a frozen gear train, although we have never needed this feature. A prototype instrument at Barrow has been operational since winter 2007 and has never had any problems with getting frozen, so we expect that the O-Buoy MAX-DOAS will move after the winter. For details on the MAX-DOAS instrument, see Carlson et al. (2009).

The instrument operated on a schedule set by the supervisory computer. When the MAX-DOAS was switched on, its computer booted and began data acquisition, typically on a half-hourly schedule. During a half-hour measurement period, the instrument performed a number of cycles (typically four) of elevation scans from horizon to zenith. A typical scan pattern observed light at 2, 5, 10, 20, and 90 degrees elevation angle on the side of the instrument away from the sun. The sun's location with reference to the MAX-DOAS instrument's view direction was calculated from the GPS location, orientation, and coordinated universal time (UTC). The tilt, frost signal, various temperatures, and raw spectra were compiled in half-hourly data "records". When the supervisory computer (SC) decided to shut down the MAX-DOAS, the $\mathrm{SC}$ requested the instrument to complete the current acquisition, archive the data to internal storage within the MAXDOAS, and pass the data to the supervisory computer to be uploaded to the satellite communications system.

The MAX-DOAS instrument consumed an average of $2.7 \mathrm{~W}$ when operating. The spectrometer consumed $0.54 \mathrm{~W}$, the stepper motor driver required $0.9 \mathrm{~W}$, and the computer used $1.3 \mathrm{~W}$. The window heater consumed around $3.8 \mathrm{~W}$ at times when the frost sensor indicated snow or frost on the window, which was typically the first two hours of daily operation.

The O-buoy MAX-DOAS system was compared to similar modules operated by University of Alaska Fairbanks, and Institute of Environmental Physics, both of which were mounted in Barrow. By comparing differential slant column density (dSCD) measurements from these three separate instruments we find that the RMS difference between the various instruments is less than $2 \times 10^{13}$ molec cm$^{-2}$ and the slope of the regressions are all within $20 \%$ of $1: 1$. Peak values of $\mathrm{BrO}$ are on the order of $4 \times 10^{14}$ molec $\mathrm{cm}^{-2}$, so the RMS variability is less than $5 \%$ of maximal values. The data also show evidence that visibility differences along each instrumental view paths increases the slope error, so we expect that further analysis of the data will lead to increased accuracy. Further details regarding the MAX-DOAS calibration are discussed in a separate paper (Carlson et al., 2009).

\subsection{Meteorological sensors and data logger}

A suite of meteorological sensors consisting of a wind monitor (RM Young Model 05103), a humidity and temperature probe (Vaisala HMP45C), and a barometer (Vaisala PTB110) were housed on the O-buoy mast. A GPS (Garmin 16HVS) was also included to determine the position of the O-buoy. For the testing phase, the ice flow did not rotate, so the orientation of the buoy was static. However, for future deployment, a solid-state compass (Ocean Server OS 5000-US) has been integrated. A Campbell data logger (CR-1000) performed five minute averages on these data, and reported the most recent five minute average to the supervisory computer on an hourly basis.

\subsection{Control systems}

\subsubsection{Supervisory computer}

The Supervisory Computer (SC) was based on a Technologic Systems TS-7260 single board computer (SBC) and additional peripheral components. The SBC had two characterbuffered, flow-controlled (16C550 type) serial communication ports, two USB 2.0 ports, a 10/100 MBps Ethernet port, an integral SPI interface, $64 \mathrm{MB}$ of RAM memory, $128 \mathrm{MB}$ of Flash memory, an SD card socket, a battery backed-up real time clock, a 16 bit PC-104 expansion interface, an on-board temperature sensor and user selectable capability for RS-232 or RS485/422 compatibility on its COM 2 serial port. Each of the above capabilities was used to operate the buoy. Its ARM9 processor was pre-specified to operate at a clock rate of $200 \mathrm{MHz}$. The software operating system was the Debian Linux distribution as adapted for the TS-7260 SBC. The SBC was fitted with an additional four-port 16C550 type serial expansion card and a second Ethernet port (these features were connected via a PC-104 expansion interface). The SBC and its options were specified at the time of purchase for operation to $-40^{\circ} \mathrm{C}$. Typical power consumption on the buoy was observed to be approximately $2.3 \mathrm{~W}$ while running a demanding computation benchmark with all ports operating at high data rates. This value may be regarded as the high end limit for SC power consumption.

Upon start-up the computer performed an initial boot from its Flash memory in the YAFFS internal file format followed by a "pivot boot" to the full operating system in EXT file format. The full Linux operating system was contained on a $512 \mathrm{MB}$ solid state disk drive. A $16 \mathrm{~GB}$ solid-state USB 


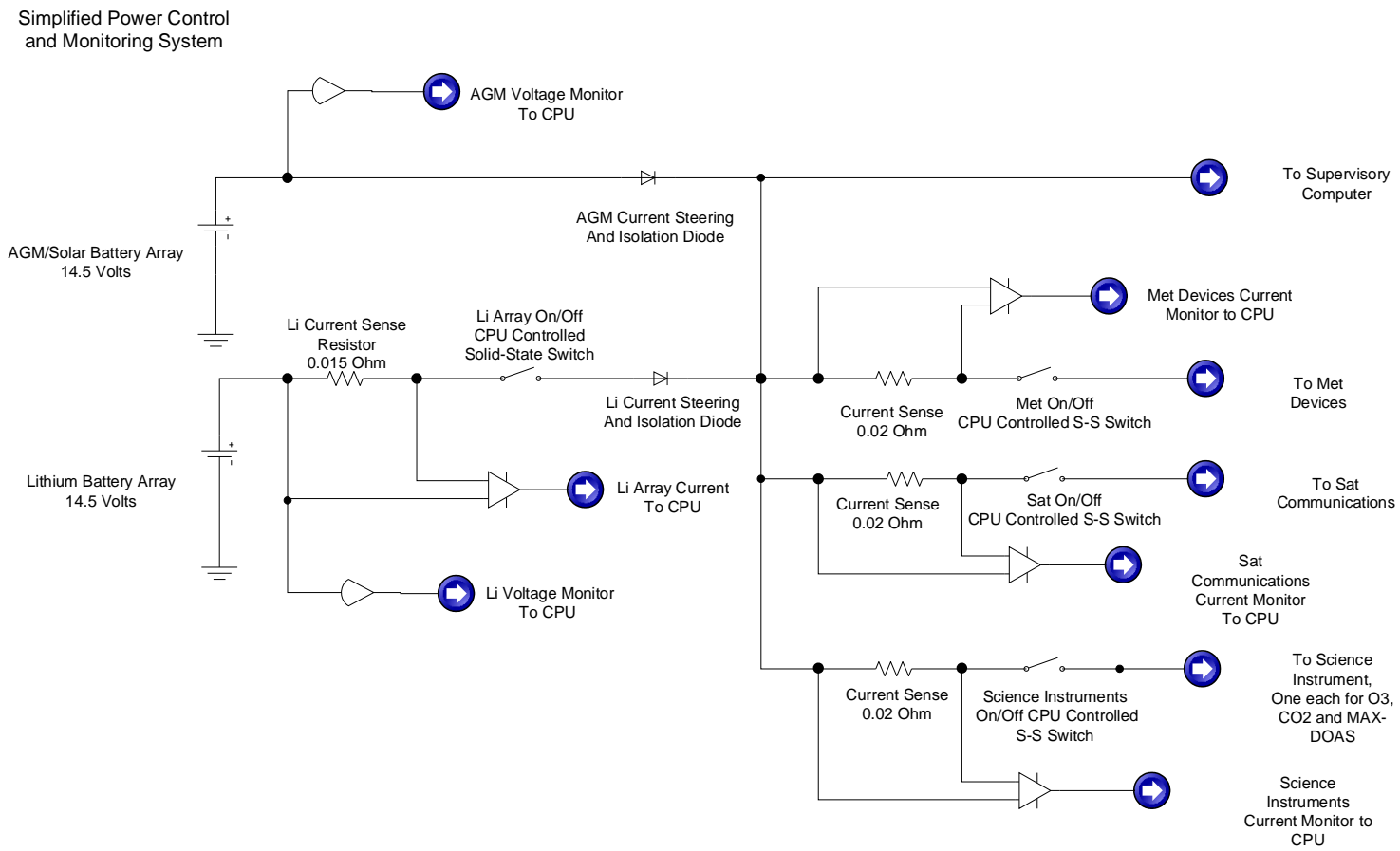

Fig. 5. Schematic representation of the power control board used on the buoy. For a full diagram see supplementary material (http://www. atmos-meas-tech.net/3/249/2010/amt-3-249-2010-supplement.pdf).

"memory stick" was installed to provide an on-board archive of all data that were obtained from every instrument and sensor.

In the event of a temporary power failure, the SC will reboot itself from firmware upon restoration of power. The SC goes through a series of system checks to ensure the integrity of its file structure on its solid-state "disk drive" before it performs a full reboot of its Linux operating system. Upon restoration of the operating system it uses the buoy's GPS device to update the day-date clock on the SC. This datum is used to restore the data acquisition and power management schedule for each instrument. Each instrument is re-initialized as it is returned to its default experimental status. Further, if the operating system can reboot as described above, the system can go into an emergency mode. It will report this state via its satellite link. Most operational software and experimental scripts can be reloaded via the satellite link by direct intervention. The link operates at 2400 bits per second, thus this process could require several days to complete and verify. In the event of loss of satellite communication the buoy will likely not be recoverable.

The SC was in continuous operation; therefore it represents the baseline power demand of the O-Buoy system. This device was the only subsystem on the buoy that was normally kept in continuous operation.

\subsubsection{Power sources/control}

Power distribution, monitoring and control were done via a custom built circuit (Fig. 5) that was directly managed by the supervisory computer. Power input was from either or both of two possible sources: (A) A conventional Lead-Acid (LA) battery bank that was recharged from a solar cell array (ASE-50-ATF/17; $50 \mathrm{~W}$ max/panel $\times 4$ panels); or (B) A non-rechargeable lithium-ion (Li) battery bank. The solar cell array was composed of four solar panels $(96.5 \mathrm{~cm} \times 45.2 \mathrm{~cm})$ connected in series, and arranged so one panel faced in each direction (N, S, E, W; Fig. 6). The power circuit was based on a negative common design. The input circuit was equipped with a separate current steering diode in series with each positive connection to the LA bank and the Li bank respectively. Additionally, an electronic switch was located "upstream" of the Li steering diode to allow the Li bank to be positively turned off by the SC under software control or explicit satellite derived command (Fig. 5). This single switch plus the two steering diodes creates three possible modes of power input to the buoy system:

1. High Solar Elevation - The Li bank is switched off by software command because the solar cells are sufficient to operate the buoy system and provide sufficient power to fully charge the LA batteries. The voltage of the LA bank is monitored by the SC through an external 12-bit digitizer and multiplexer. As long as the LA voltage 


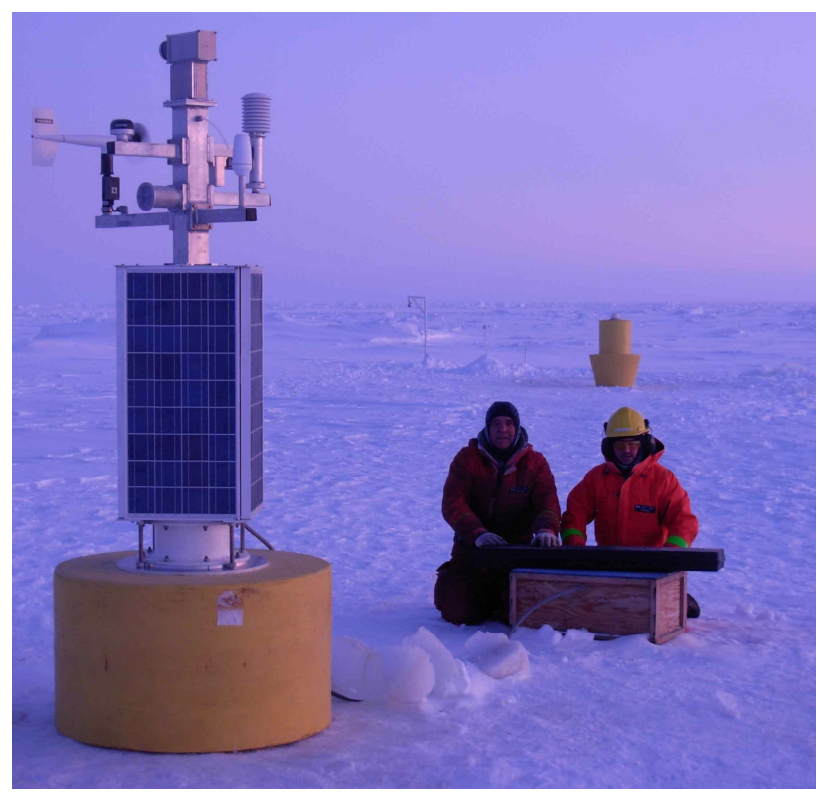

Fig. 6. Photograph of the O-buoy, solar panel array, and lead-acid battery box as deployed on the Beaufort Sea. The lead acid packs (inside wooden box) are connected to the buoy via shielded cable in a manner that allows the lead acid batteries to tear away from the buoy in the event of a significant ice break up. Should this happen, the buoy will stay on via diode switching with power from the internal lithium ion packs. Future versions will have larger flotation collars with cavities to store the lead acid batteries.

cycles between 14.5 volts and 11.5 volts the LA pack will be the source of power. This voltage range is determined by a pulse width modulated controller (Morningstar SS-10) that arbitrates between the unregulated solar array and the LA battery bank.

2. Solar Elevation Near or Below the Horizon - The solar cells may not be capable of maintaining the charge on the LA batteries (LA voltage level falls to $\leq 11.5 \mathrm{~V}$ ). At this control point, the SC software turns on the Li bank. The Li batteries will exhibit an open circuit voltage above this level $(>11.5 \mathrm{~V})$ until they are almost completely exhausted. Our calculations indicate that the Li battery bank will last at least one winter for normal operation of the buoy.

3. Intermediate Solar Elevation - The solar array is able to provide significant power to the buoy via scattering from the sky and ice surfaces at intermediate solar angle. Both battery banks are on line where passive diode steering alone apportions the current load. This mode was tested during the deployment in Elson Lagoon from February-May 2009. Despite the sun being not much above the horizon, the solar array provided sufficient power to operate the buoy from the LA bank charge alone on a $24 \mathrm{~h}$ basis by mid-March 2009 .
Power distribution was managed by the SC via the power control circuit. Identical electronic switches supplied the unregulated DC power to all scientific devices, meteorological instruments and a pre-packaged satellite transceiver system. The power control circuit provided regulated voltage at +3.3 volts for its own analog and digital circuits. This circuit utilized a set of voltage and current sensing amplifiers which were read via a multi-input multiplexer via the SPI port on the SBC. There were sufficient parameters available that the system software could report the distributed voltage level and all significant current loads in the system.

\subsubsection{Scheduling}

Based on a predetermined scientific observation schedule (which was based, in turn, on the solar elevation angle), individual instruments were sequenced into operation as needed. The objective was to provide a maximum number of scientific observations achievable with the power available (maximum of $16 \mathrm{~W}$ ). The power consumption of each instrument and the SC is shown in Table 1. The satellite transceiver is excluded due to its great variability. Scientific functions were scheduled for operation and data acquisition between satellite service intervals (once every $24 \mathrm{~h}$ for a $2 \mathrm{~h}$ interval). Typically data from the buoy were uploaded to the satellite during this time. Revised programs and schedules could also be downloaded to the O-buoy during an open satellite window. The results of these changes were seen at the next satellite window for the buoy $24 \mathrm{~h}$ later.

A more power efficient version of the SC system is now being developed. It is practical to reduce the power consumption of this part of the buoy system by a factor of two. This improvement may extend the unattended lifetime of the buoy to two years of operation in high latitude polar environments.

\subsection{Communications}

Satellite communication was done through an Iridium phone (NAL Research AL3A-SA). All communication to and from the buoy was achieved through this transceiver and was controlled by the SC. During transmission, the files (typically totaling $>200 \mathrm{~KB}$ ) were aggregated and put into $10 \mathrm{~KB}$ chunks to limit the amount of data required to be resent should the transmitting signal be temporarily interrupted. Moreover, the data were routinely backed-up on the SC in case all transmission capabilities were lost. The data were transferred from the SC every day at 18:00 UTC, and were sent to a temporary repository at SRI International where it could be accessed by the various groups involved via an Internet connection.

\section{Deployment}

The O-buoy was field tested in Elson Lagoon at Barrow, Alaska from 3 February to 18 May 2009. The O-buoy was transported from Barrow to the deployment site by a sled pulled by snow-machine. A two meter long, half meter wide, 
slit was cut in the sea-ice (approximately $1 \mathrm{~m}$ thick) to allow the O-buoy to be slid off the sled horizontally, and allow the bottom to be lowered into the slit, thus positioning the O-buoy in a fully upright configuration (Fig. 6; http:// www.youtube.com/watch?v=2ijCZ_arhzE for video). In October of 2009 the buoy was re-deployed in the Beaufort Sea, at $76^{\circ} \mathrm{N}, 138^{\circ} \mathrm{W}$, where it is still located. The buoy was transported via the CCGS Louis S. St. Laurent, and then via helicopter to its current location.

\section{Results and conclusions}

The data and associated metadata obtained during this field test can be found at http://www.aoncadis.org. As an example of the quality of data obtained from the O-buoy we present the data collected in 2009 at both sites in Figs. 7-8. The data depict the frequent ODEs during spring, but more stable ozone mole fractions in the fall. For the first deployment near Barrow, we compared our $\mathrm{O}_{3}$ data with those measured at the NOAA lab in the Barrow Environmental Observatory. While it is quite possible that there are actual differences in ozone mole fraction at the two locations (5 km apart; the O-Buoy is on sea ice, while the NOAA lab is on the tundra), the average difference in ozone at the two locations over this period was $1.6 \mathrm{ppb}$. We note that the wind speed measurement (Fig. 8) may be in error, as our recorded wind speeds are significantly different from those measured at the ESRL site at low wind speeds. This is most likely due to icing on the anemometer's propeller.

From the data collected it can be seen that the O-buoy system is fully operational and capable of functioning for extended periods of time in the harsh Arctic environment. We present these data as a proof of concept that such measurements are achievable over long periods, thus providing invaluable information regarding atmospheric chemistry and composition in the Arctic environment.

\section{Future work}

The first buoy is currently collocated with buoys measuring ice mass balance and the physical properties of the upper ocean creating an automated drifting station. Given the success of the O-buoy, additional units will be constructed and deployed throughout the Arctic Ocean to provide a better understanding of where and how chemistry and composition in the Arctic are changing, and to further study and observe any future variations in Arctic atmospheric chemical composition and meteorological parameters. Data from these buoys could be used to evaluate satellite measurements, and to improve their interpretation. The MAX-DOAS instrument is selectively sensitive to tropospheric chemical species (whereas satellites measure total column abundances). By making a comparison between long term $\mathrm{O}_{3}$ and $\mathrm{BrO}$ measurements on the buoy we will learn more about their relationship in

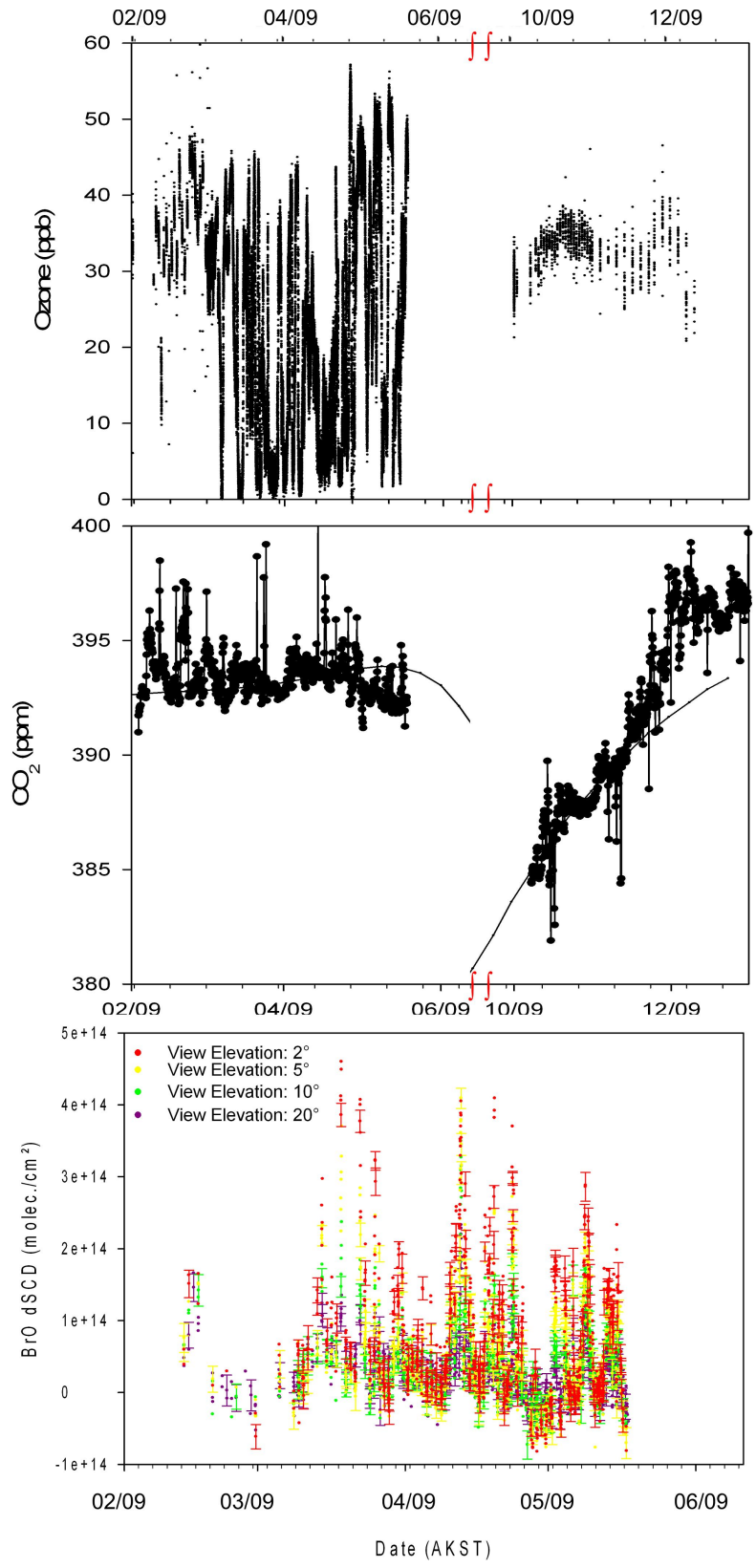

Fig. 7. Data plots from the three major instruments on the O-buoy $\left(\mathrm{O}_{3}, \mathrm{CO}_{2}\right.$, and $\left.\mathrm{BrO}\right)$ during the entire test phase deployment and the current Beaufort Sea deployment (date in $\mathrm{mm} / \mathrm{yy}$ ). The ozone and $\mathrm{CO}_{2}$ plots' abscissas are broken after $06 / 09$, as indicated by $\iint$. Note, $\mathrm{BrO}$ is plotted for only the spring period due to inadequate sample time (result of low sunlight) during the Fall deployment. The smoothed line in the $\mathrm{CO}_{2}$ plot is a NOAA derived decadal average.

the troposphere, with the opportunity to compare these data with satellite measurements to improve their inversions. The O-buoy will also prove very useful in observing changes in $\mathrm{CO}_{2}$ with future changes in Arctic Ocean surface conditions. 


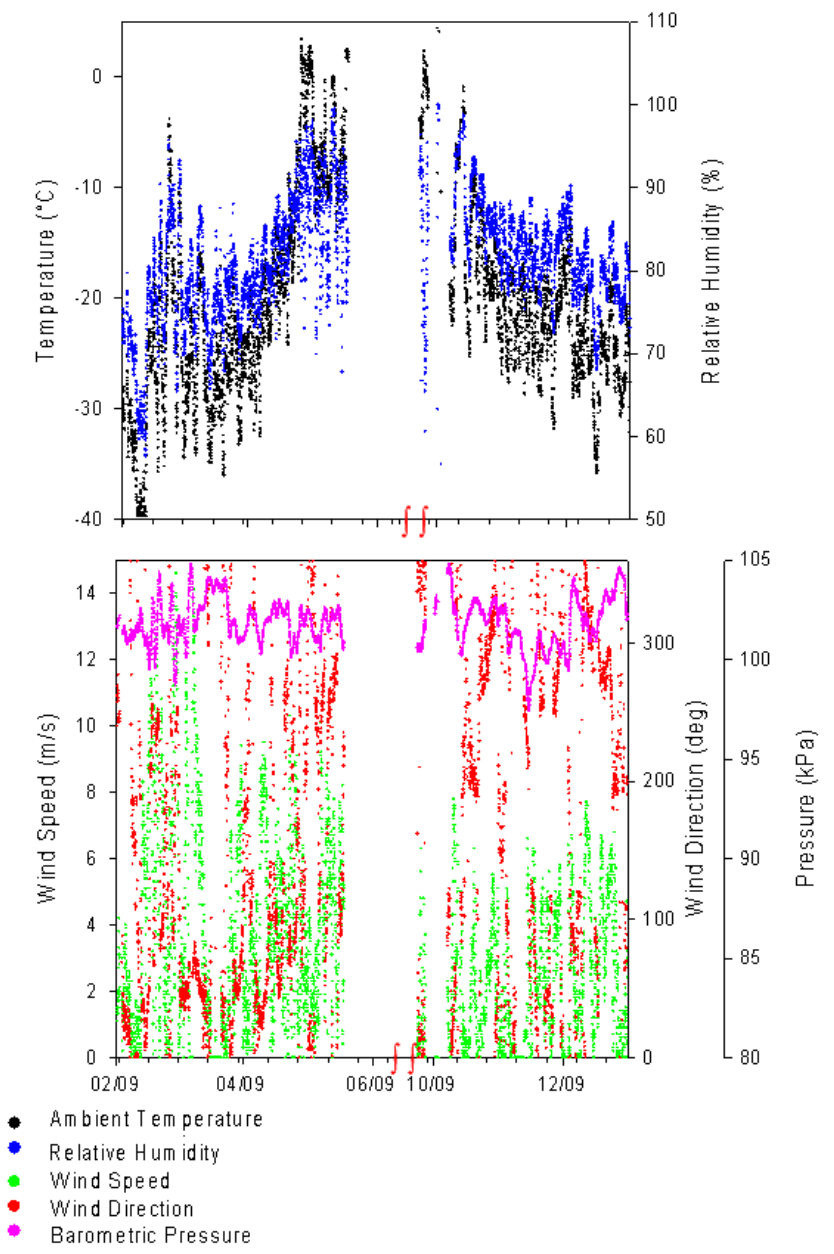

Fig. 8. Plot of the meteorological data acquired on the O-buoy during 2009. Note, the abscissas have a break.

Acknowledgements. We thank the NSF for funding this work through grants No. ARC-0612331, ARC-0611992, ARC-0612047, and ARC-0612457 to P. Matrai, D. Perovich, P. Shepson, and W. Simpson, respectively, and the Canadian Government's Federal Program Office for the International Polar Year No. MD065, "OASIS-CANADA".

We thank Lewis Brower and the staff at the Barrow Arctic Science Consortium for their generous logistical help; Pieter Tans, NOAA ESRL for making the CCGG daily $\mathrm{CO}_{2}$ data from the Barrow, $\mathrm{AK}$ Observatory available; the Jonathan Amy facility for Chemical Instrumentation at Purdue University for machining and electrical work; and Sam Oltmans, NOAA ESRL for the Barrow, AK ozone data.

Edited by: J. Stutz

\section{References}

Alvarez-Aviles, L., Simpson, W. R., Douglas, T. A., Sturm, M., Perovich, D., and Dominé, F.: Frost flower chemical composition during growth and its implications for aerosol production and bromine activation, J. Geophys. Res.-Atmos., 113, D21304, doi:21310.21029/22008JD010277, 2008.

Barrie, L. A., Bottenheim, J. W., Schnell, R. C., Crutzen, P. J., and Rasmussen, R. A.: Ozone destruction and photochemical reactions at polar sunrise in the lower Arctic atmosphere, Nature, 334, 138-141, 1988.

Battle, M., Bender, M. L., Tans, P. P., White, J. W. C., Ellis, J. T., Conway, T., and Francey, R. J.: Global carbon sinks and their variability inferred from atmospheric O-2 and delta C-13, Science, 287, 2467-2470, 2000.

Bottenheim, J. W., Gallant, A. G., and Brice, K. A.: Measurements of $\mathrm{NO}_{\mathrm{y}}$ Species and O-3 at 82-Degrees-N Latitude, Geophys. Res. Lett., 13, 113-116, 1986.

Bottenheim, J. W., Netcheva, S., Morin, S., and Nghiem, S. V.: Ozone in the boundary layer air over the Arctic Ocean: measurements during the TARA transpolar drift 2006-2008, Atmos. Chem. Phys., 9, 4545-4557, 2009, http://www.atmos-chem-phys.net/9/4545/2009/.

Carlson, D., Donohoue, D., Platt, U., and Simpson, W. R.: A low power automated MAX-DOAS instrument for the Arctic and other remote unmanned locations, Atmos. Meas. Tech. Discuss., 2, 2347-2375, 2009, http://www.atmos-meas-tech-discuss.net/2/2347/2009/.

Ciais, P., Tans, P. P., Trolier, M., White, J. W. C., and Francey, R. J.: A Large Northern-Hemisphere Terrestrial $\mathrm{CO}_{2}$ Sink Indicated by the C-13/C-12 Ratio of Atmospheric $\mathrm{CO}_{2}$, Science, 269, 1098 $1102,1995$.

Comiso, J. C.: A rapidly declining perennial sea ice cover in the Arctic, Geophys. Res. Lett., 29, 1956, doi:1910.1029/2002GL015650, 2002.

Ding, J. T., Griggs, D. J., Noguer, M., van der Linden, P. J., Dai, X., Maskell, K., and Johnson, C. A.: Climate Change 2001: Synthesis Report: Third Assessment Report of the Intergovernmental Panel on Climate Change, Intergovernmental panel on Climate Change, Cambridge, UK, New York, NY USA, 2001.

Dominé, F. and Shepson, P. B.: Air-snow interactions and atmospheric chemistry, Science, 297, 1506-1510, 2002.

Dominé, F., Taillandier, A. S., Simpson, W. R., and Severin, K.: Specific surface area, density and microstructure of frost flowers, Geophys. Res. Lett., 32, L13502, doi:10.1029/2005GL023245, 2005.

Fan, S. M. and Jacob, D. J.: Surface Ozone Depletion in Arctic Spring Sustained by Bromine Reactions on Aerosols, Nature, 359, 522-524, 1992.

Foster, K. L., Plastridge, R. A., Bottenheim, J. W., Shepson, P. B., Finlayson-Pitts, B. J., and Spicer, C. W.: The role of Br-2 and $\mathrm{BrCl}$ in surface ozone destruction at polar sunrise, Science, 291, 471-474, 2001.

Friederich, G. E., Brewer, P. G., Herlien, R., and Chavez, F. P.: Measurement of Sea-Surface Partial-Pressure of $\mathrm{CO}_{2}$ from a Moored Buoy, Deep-Sea Res. Pt I, 42, 1175-1186, 1995.

Friederich, G. E., Ledesma, J., Ulloa, O., and Chavez, F. P.: Air-sea carbon dioxide fluxes in the coastal southeastern tropical Pacific, Prog. Oceanogr., 79, 156-166, 2008. 
Haas, C., Pfaffling, A., Hendricks, S., Rabenstein, L., Etienne, J. L., and Rigor, I.: Reduced ice thickness in Arctic Transpolar Drift favors rapid ice retreat, Geophys. Res. Lett., 35, L17501, doi:17510.11029/12008GL034457, 2008.

Holland, M. M., Bitz, C. M., and Tremblay, B.: Future abrupt reductions in the summer Arctic sea ice, Geophys. Res. Lett., 33, L23503, doi:23510.21029/22006GL028024, 2006.

Hönninger, G. and Platt, U.: Observations of $\mathrm{BrO}$ and its vertical distribution during surface ozone depletion at Alert, Atmos. Environ., 36, 2481-2489, 2002.

Hönninger, G., von Friedeburg, C., and Platt, U.: Multi axis differential optical absorption spectroscopy (MAX-DOAS), Atmos. Chem. Phys., 4, 231-254, 2004, http://www.atmos-chem-phys.net/4/231/2004/.

Impey, G. A., Shepson, P. B., Hastie, D. R., Barrie, L. A., and Anlauf, K. G.: Measurements of photolyzable chlorine and bromine during the Polar sunrise experiment 1995, J. Geophys. Res.Atmos., 102, 16005-16010, 1997.

Jacobi, H. W., Kaleschke, L., Richter, A., Rozanov, A., and Burrows, J. P.: Observation of a fast ozone loss in the marginal ice zone of the Arctic Ocean, J. Geophys. Res.-Atmos., 111, D15309, doi:15310.11029/12005JD006715, 2006.

Johannessen, O. M., Bengtsson, L., Miles, M. W., Kuzmina, S. I., Semenov, V. A., Alekseev, G. V., Nagurnyi, A. P., Zakharov, V. F., Bobylev, L. P., Pettersson, L. H., Hasselmann, K., and Cattle, H. P.: Arctic climate change: observed and modeled temperature and sea-ice variability, Tellus A, 56, 559-560, 2004.

Kaleschke, L., Richter, A., Burrows, J., Afe, O., Heygster, G., Notholt, J., Rankin, A. M., Roscoe, H. K., Hollwedel, J., Wagner, T., and Jacobi, H. W.: Frost flowers on sea ice as a source of sea salt and their influence on tropospheric halogen chemistry, Geophys. Res. Lett., 31, L16114, doi:16110.11029/12004GL020655, 2004.

Kalnajs, L. E. and Avallone, L. M.: Frost flower influence on springtime boundary-layer ozone depletion events and atmospheric bromine levels, Geophys. Res. Lett., 33, L10810, doi:10810.11029/12006GL025809, 2006.

Keeling, R. F., Piper, S. C., and Heimann, M.: Global and hemispheric $\mathrm{CO}_{2}$ sinks deduced from changes in atmospheric O-2 concentration, Nature, 381, 218-221, 1996.

Leckrone, K. J. and Hayes, J. M.: Efficiency and temperature dependence of water removal by membrane dryers, Anal. Chem., 69, 911-918, 1997.

Lindsay, R. W. and Zhang, J.: Arctic ocean ice thickness: Modes of variability and the best locations from which to monitor them, J. Phys. Oceanogr., 36, 496-506, 2006.

Oltmans, S. J. and Komhyr, W. D.: Surface Ozone Distributions and Variations from 1973-1984 Measurements at the NOAA Geophysical Monitoring for Climatic-Change Base-Line Observatories, J. Geophys. Res.-Atmos., 91, 5229-5236, 1986.

Papakyriakou, T. N., Miller, L. A., Langlois, A., Mundy, C., and O'Driscoll, P.: Sea ice and $\mathrm{CO}_{2}$ exchange in the Canadian Arctic, SOLAS Science 2004: A SOLAS open science conference, Halifax, Canada, 13-16 October 2004, \#75, 2004.
Proshutinsky, A., Yang, J., Krishfield, R., Gerdes, R., Karcher, M., Kauker, F., Koeberle, C., Hakkinen, S., Hibler, W., Holland, D., Maqueda, M., Holloway, G., Hunke, E., Maslowski, W., Steele, M., and Zhang, J.: Arctic Ocean Study: Synthesis of Model Results and Observations, EOS T. Am. Geophys. Un., 86, 368-371, 2005.

Rankin, A. M., Auld, V., and Wolff, E. W.: Frost flowers as a source of fractionated sea salt aerosol in the polar regions, Geophys. Res. Lett., 27, 3469-3472, 2000.

Richter, A., Wittrock, F., Eisinger, M., and Burrows, J. P.: GOME observations of tropospheric $\mathrm{BrO}$ in northern hemispheric spring and summer 1997, Geophys. Res. Lett., 25, 2683-2686, 1998.

Rigor, I. G., Colony, R. L., and Martin, S.: Variations in surface air temperature observations in the Arctic, 1979-97, J. Climate, 13, 896-914, 2000.

Semiletov, I., Makshtas, A., Akasofu, S. I., and Andreas, E. L.: Atmospheric $\mathrm{CO}_{2}$ balance: The role of Arctic sea ice, Geophys. Res. Lett., 31, L05121, doi:05110.01029/02003GL017996, 2004.

Simpson, W. R., Alvarez-Aviles, L., Douglas, T. A., and Sturm, M.: Halogens in the coastal snow pack near Barrow, Alaska: Evidence for active bromine air-snow chemistry during springtime, Geophys. Res. Lett., 32, L04811, doi:10.1029/2004GL021748, 2005.

Simpson, W. R., Carlson, D., Hnninger, G., Douglas, T. A., Sturm, M., Perovich, D., and Platt, U.: First-year sea-ice contact predicts bromine monoxide $(\mathrm{BrO})$ levels at Barrow, Alaska better than potential frost flower contact, Atmos. Chem. Phys., 7, 621-627, 2007a, http://www.atmos-chem-phys.net/7/621/2007/.

Simpson, W. R., von Glasow, R., Riedel, K., Anderson, P., Ariya, P., Bottenheim, J., Burrows, J., Carpenter, L. J., Frieß, U., Goodsite, M. E., Heard, D., Hutterli, M., Jacobi, H.-W., Kaleschke, L., Neff, B., Plane, J., Platt, U., Richter, A., Roscoe, H., Sander, R., Shepson, P., Sodeau, J., Steffen, A., Wagner, T., and Wolff, E.: Halogens and their role in polar boundary-layer ozone depletion, Atmos. Chem. Phys., 7, 4375-4418, 2007b, http://www.atmos-chem-phys.net/7/4375/2007/.

Strabo: Geographica, 1966 ed., Lipsiae: B.G. Teubneric, Leipzig, Germany, 1966.

Stroeve, J., Holland, M. M., Meier, W., Scambos, T., and Serreze, M.: Arctic sea ice decline: Faster than forecast, Geophys. Res. Lett., 34, L09501, doi:09510.01029/02007GL029703, 2007.

Tang, T. and McConnell, J. C.: Autocatalytic release of bromine from Arctic snow pack during polar sunrise, Geophys. Res. Lett., 23, 2633-2636, 1996.

Wagner, T. and Platt, U.: Satellite mapping of enhanced BrO concentrations in the troposphere, Nature, 395, 486-490, 1998.

Warren, S. H.: Arctic plants from the valley gravels of the River Lea, Nature, 85, 206-206, 1911.

Weller, R. and Schrems, O.: Photooxidants in the marine Arctic troposphere in summer, J. Geophys. Res.-Atmos., 101, 91399147, 1996.

Whitfield, R. P.: Observations on and descriptions of Arctic fossils, Bulletin of the American Museum of Natural History, 13, 19U10, 1900. 